\title{
Changes on facial profile in the mixed dentition, from natural growth and induced by Balters' bionator appliance
}

Denise Rocha Goes Landázuri¹, Dirceu Barnabé Raveli², Ary dos Santos-Pinto², Luana Paz Sampaio Dib³, Savana Maia ${ }^{4}$

Objective: The purpose of this study was to evaluate the facial profile changes induced by Balters' bionator appliance in Class II division 1 patients, at mixed dentition stage. Methods: The sample consisted of 28 prepubertal individuals at stages 1 and 2 of skeletal maturation (CVM), which were divided in two groups. The experimental group consisted of 14 individuals ( 7 boys and 7 girls, initial mean age of $8 \mathrm{y} 12 \mathrm{~m}$ ) which were treated with Balters' bionator appliance for 14.7 months. The effects of treatment were compared to a control group of 14 subjects ( 7 boys and 7 girls, initial mean age of $8 \mathrm{y} 5 \mathrm{~m}$ ) with Class II malocclusion, division 1, not orthodontically treated, which were followed up for 15.4 months. The statistical analysis was performed using Student's $t$ test, at a significance level of 5\%. Results: The results showed that the Balters' bionator appliance promoted a significant increase on the mentolabial angle, in addition to demonstrating a tendency to reduce the facial skeletal convexity, to restrict the maxillary growth and to increase the nasolabial angle and the lower anterior facial height. Conclusion: It can be concluded that the Balters' bionator appliance improved the facial profile of children treated at mixed dentition stage.

Keywords: Activator appliances. Angle Class II malocclusion. Cephalometry.

Objetivo: o objetivo desse estudo foi avaliar as alterações no perfil facial induzidas pelo uso do Bionator de Balters em indivíduos com má oclusão Classe II divisão 1, na fase da dentição mista. Métodos: a amostra consistiu de 28 pacientes, pré-pubertários, que se encontravam nos estágios 1 e 2 de maturação esquelética (CVM), os quais foram divididos em dois grupos. O grupo experimental foi constituído por 14 indivíduos $(7$ meninos e 7 meninas, média de idade inicial de 8 anos e 12 meses) que foram tratados com o Bionator de Balters por um período médio de 14,7 meses. Os efeitos do tratamento foram comparados com um grupo controle de 14 indivíduos (7 meninos e 7 meninas, média de idade inicial de 8 anos 5 meses) Classe II divisão 1, não tratados ortodonticamente, que foram acompanhados por um período médio de 15,4 meses. A análise estatística foi realizada por meio do teste $t$ de Student, com nível de significância de 5\%. Resultados: os resultados indicaram que o o bionator de Balters promoveu um aumento significativo do ângulo mentolabial, além de demonstrar tendência à diminuição da convexidade esquelética facial, à restrição do crescimento maxilar e ao aumento do ângulo nasolabial e da altura facial anteroinferior. Conclusão: pode-se concluir que o Bionator de Balters melhorou o perfil facial de crianças tratadas na fase da dentição mista.

Palavras-chave: Aparelhos ativadores. Má oclusão de Angle Classe II. Cefalometria.

${ }^{1}$ Master and Doctor in Orthodontics, Dental School of Araraquara - State University of São Paulo (FOA-UNESP).

${ }^{2}$ Associate Professor of Orthodontics, FOA-UNESP.

${ }^{3}$ Doctor in Orthodontics, FOA-UNESP. Associate professor at the specialization program in Orthodontics, FAMOSP - GESTOS.

${ }^{4}$ Doctor in Orthodontics, FOA-UNESP. Professor at the State University of Amazonas.

Submitted: September 24, 2008 - Revised and accepted: February 28, 2010
How to cite this article: Landázuri DRG, Raveli DB, Santos-Pinto A, Dib LPS, Maia S. Changes on facial profile in the mixed dentition, from natural growth and induced by Balters' bionator appliance. Dental Press J Orthod. 2013 Mar-Apr;18(2):108-15.

» The authors report no commercial, proprietary or financial interest in the products or companies described in this article.

Contact address: Denise Rocha Goes Landázuri Av. Portugal, 887 - Centro - Araraquara/SP, Brazil CEP: 14.801-075 - E-mail: denisergoes@gmail.com 


\section{INTRODUCTION}

Achieving an esthetically pleasing face is one of the main goals of orthodontic treatment, and since the beginning of orthodontics, great researchers such as Kingsley, ${ }^{16}$ Case $^{10}$ and Angle ${ }^{3}$ emphasized the importance of the interrelation between esthetics and this specialty. However, to achieve this goal, it is necessary that the orthodontist deeply understand not only the biomechanical aspects related to tooth movement, but also the continuous changes that occur during facial growth and development of natural individuals. ${ }^{27}$

The introduction of cephalostat in dentistry ${ }^{9}$ allowed the standardization of lateral teleradiography and allowed the accomplishment of more accurate dentoskeletal and facial profile assessments. Thus, combining the results of cephalometric analysis associated to clinical and subjective examination by each professional will enable the achievement of an ideal occlusion with functional stability and facial esthetic. ${ }^{1,20,26}$

Despite the various cephalometric analysis proposed in literature, initially, little emphasis was given to the analysis of the soft tissue profile, due to the inadequate concept that changes on soft tissue would accurately follow the repositioning of subjacent skeletal and dental tissues. ${ }^{19}$ Currently, it is known that due to the large variability inherent to soft tissues - such as thickness and tonicity, especially of the lips - , they can mitigate or protrude the contours of the subjacent anatomical structures.

The concept of the ideal profile has been discussed in literature ${ }^{8,14,23,25}$ and despite of accepting variations due to differences among races, countries, culture and time, the straight or slightly convex profile is still synonymous of beauty. As the aspect of the facial profile in patients with Class II malocclusion, division 1, with mandibular retrusion is quite convex, one of the main goals of this treatment is to improve facial aesthetics, by reducing the profile convexity. ${ }^{22}$

Class II malocclusions are characterized by an imbalance between bone bases in the anteroposterior direction, which can result in maxillary basal protrusion, maxillary dentoalveolar protrusion, mandibular deficiency, mandibular dentoalveolar retrusion or a combination of these factors. ${ }^{12,15}$ This maxillomandibular discrepancy is present in a significant percentage of the population, ${ }^{18,30}$ and is considered the most frequent in orthodontics practice. In Brazil, according to an epidemiological study conducted by Silva Filho et al, ${ }^{29}$ with 2,016 children of 07-11 years-old, both genders, Class II malocclusion showed a prevalence of $42 \%$, being $27 \%$ of dental origin and $15 \%$ considered as skeletal Class II. Thus, it explains the large number of patients with this clinical feature who seek orthodontic clinics to address the esthetic and functional problems triggered by this malocclusion.

The treatment of Class II malocclusion, division 1, with mandibular deficiency in growing patients aims the mandibular advancement, to achieve better relations between bone bases and improve the convex facial profile. Among the functional orthodontic devices intended for this purpose, Balters' bionator is highlighted. It was developed by Wilhelm Balters in the 50's. ${ }^{13}$ He believed that improper posture of the tongue, which was placed in a retruded manner, would be responsible for a disturbance in cervical region, change in respiratory function, atypical deglutition and consequent impairment of mandibular growth. ${ }^{5}$ Therefore, Balters designed a device to promote an anterior mandibular positioning, enabling the tongue to occupy a normal intraoral position and, also, lip competence. ${ }^{19}$

The few data reported in the literature about possible changes on facial profile of children with Class II malocclusion, division 1, due to mandibular retrusion treated with Balters' bionator, led us to evaluate the effect of treatment with this device.

\section{PURPOSE}

The aim of this study was to provide data to assess changes in the facial profile resulting from natural growth and induced by the use of Balters' bionator device in children, before the growth peak of the pre-pubertal period, more specifically in stages 1 and 2 of skeletal maturation, observed through the analysis of cervical vertebrae.

\section{MATERIAL AND METHODS \\ Material}

The sample used in this study was obtained from two distinct populations: Brazilian and Canadian. Individuals were divided into two groups: the experimental group treated with Balters' bionator and a control group that received no orthodontic treatment.

\section{Experimental group}

The experimental group consisted of 14 patients treated with Balters' bionator, 7 males and 7 females. The inclusion criteria used were: Class II division 1 facial pattern, associated with mandibular retrusion; Class II, 
division 1, dental relation; permanent upper and lower central and lateral incisors erupted or erupting, no mandibular crowding, 5-7 mm overjet, mixed dentition and absence of cross-sectional problems.

All patients were treated with Balters' bionator, which was based on the original design proposed by Balters ${ }^{5}$ and adapted by Ascher, ${ }^{2}$ having the acrylic extension of the lower arch deeper than the original, and covering the incisal and cusps of the incisors and canines, respectively (Fig 1), so that the effect of inclination of the lower incisors was decreased.

The mandibular advancement was carried out in a unique way to obtain a cusp to cusp relation with incisors and, for patients whose overjet was more accentuated, the reference was the canine relation in Class I. For these cases, the treatment was carried out in two phases: The first phase with canine relation in Class I, and the second phase with the incisors in a cusp to cusp relation.

\section{Control group}

The control group was selected from the documentation files of the Burlington Growth Centre, located in the Department of Orthodontics, Faculty of Dentistry, University of Toronto, Canada. This sample consisted of 14 individuals, 7 males and 7 females, randomly selected from a group of 20 individuals. Selection criteria for this group were: Class II division 1 facial pattern, associated with mandibular retrusion; Class II division 1 dental relation; upper and lower central incisors erupted, mixed dentition and no previous orthodontic treatment.

These individuals were randomly paired with patients of the same gender from the experimental group, and selected the observation times that corresponded to the age, in complete years, of the respective pair.

The descriptive data about age and time of treatment for the experimental and control groups are shown in Tables 1 and 2, respectively.

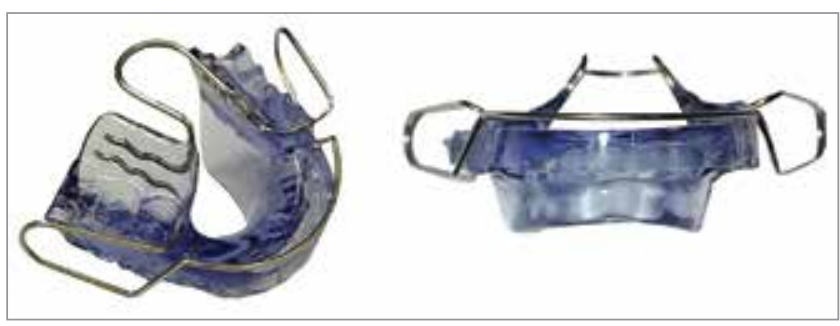

Figure 1 - Side and front view of Balters' bionator.

\section{Determination of skeletal maturation}

The determination of skeletal age was verified through lateral teleradiographies, using the indicators of skeletal maturation of cervical vertebrae. The bone age determination was performed by the same operator and in a blind study, i.e., without identification of the patient evaluated, which reduces the subjectivity of this evaluation. Thus, the selected individuals were located in the maturation stages 1 and 2, i.e., before the growth peak of pre-pubertal period, according to Baccetti, Franchi, McNamara; ${ }^{4}$ O'Reilly and Yanniello. ${ }^{21}$

\section{METHODS}

For each individual, it were obtained two lateral cephalograms, called $\mathrm{T}_{1}$ (beginning of treatment) and $\mathrm{T}_{2}$ (end of treatment), for the experimental group; and $\mathrm{T}_{1}$ (beginning of the observation period) and $\mathrm{T}_{2}$ (end of the observation period) for the control group.

Although the radiographs had been obtained by different X-ray equipments, it was not performed a correction for image magnification. The difference of

Table 1 - Descriptive data of patients' ages in experimental and control groups, according to gender and treatment stage.

\begin{tabular}{|c|c|c|c|c|}
\hline & \multicolumn{2}{|c|}{ Experimental } & \multicolumn{2}{|c|}{ Control } \\
\hline & Mean & SD & Mean & SD \\
\hline \multicolumn{5}{|l|}{ Female } \\
\hline Baseline & $8 y 9 m$ & $6 m$ & $8 y 3 m$ & $6 m$ \\
\hline End & $10 y 2 m$ & $4 m$ & $9 y 9 m$ & $6 m$ \\
\hline \multicolumn{5}{|l|}{ Male } \\
\hline Baseline & $9 y 2 m$ & $5 \mathrm{~m}$ & $8 y 7 m$ & $6 \mathrm{~m}$ \\
\hline End & 10y 3m & $5 m$ & $9 y 9 m$ & $6 m$ \\
\hline \multicolumn{5}{|l|}{ Both } \\
\hline Baseline & $8 y$ 12m & $6 m$ & $8 y 5 m$ & $6 m$ \\
\hline End & $10 y 3 m$ & $5 \mathrm{~m}$ & $9 y 9 m$ & $6 \mathrm{~m}$ \\
\hline
\end{tabular}

Table 2 - Descriptive data of treatment period, in months, of the patients in experimental and control groups, according to gender.

\begin{tabular}{ccccc}
\hline & \multicolumn{2}{c}{ Experimental } & \multicolumn{2}{c}{ Control } \\
\cline { 2 - 5 } & Mean & SD & Mean & SD \\
Female & 16.7 & 4.6 & 17.1 & 6.4 \\
Male & 12.4 & 1.7 & 13.7 & 4.5 \\
Both & 14.6 & 4.0 & 15.4 & 5.6 \\
\hline
\end{tabular}


magnification percentage between samples would be $0.16 \%$, which would not affect the comparison of the variables displayed in radiographs obtained by different X-ray devices. This difference in image magnification corresponds to a difference in magnification between X-rays of $0.0016 \mathrm{~cm}(0.016 \mathrm{~mm})$.

All radiographs were traced by hand by the same operator, the cephalometric points were digitized on a $\mathrm{Nu}-$ monics AccuGrid tablet, and evaluated through Dentofacial Planner Plus 2.01 computer software for obtaining cephalometric measurements.

\section{Obtaining cephalometric measurements}

The cephalometric measures used in this study are shown in Table 3 and Figure 2.

\section{Statistical analysis}

To evaluate the data, the following statistical tests were performed:

"Student's t-test for the equality of means of two independent populations: To examine the hypothesis that the mean of each measure in the control group did not differ from the mean of the experimental group at baseline (Table 4).

" Student's t-test for the equality of means of two populations with independent samples: To examine the hypothesis that the changes observed in a cephalometric measure between times 1 and 2 do not differ, in terms of means, in the control group and the experimental group (Table 5).
Table 3 - Cephalometric measures evaluated.

\begin{tabular}{|c|c|}
\hline $\begin{array}{l}\text { Cephalometric } \\
\text { measures }\end{array}$ & Definition \\
\hline 1) Convex & $\begin{array}{l}\text { Supplement of the angle that measures the convexity of } \\
\text { the bone profile }\end{array}$ \\
\hline 2) LAFH & $\begin{array}{l}\text { Linear measure that represents the height of the lower } \\
\text { anterior facial third }\end{array}$ \\
\hline 3) $\mathrm{SNA}$ & $\begin{array}{l}\text { Represents the anteroposterior position of the maxilla in } \\
\text { relation to the anterior cranial base }\end{array}$ \\
\hline 4) $S N B$ & $\begin{array}{l}\text { Represents the anteroposterior position of the mandible } \\
\text { in relation to the anterior cranial base }\end{array}$ \\
\hline 5) U1PP & $\begin{array}{l}\text { Angle formed by the long axis of the upper incisor and } \\
\text { the palatal plane }\end{array}$ \\
\hline 6) $L 1 M P$ & $\begin{array}{l}\text { Angle formed by the long axis of the lower incisor and } \\
\text { the mandibular plane }\end{array}$ \\
\hline 7) U1L1 & $\begin{array}{l}\text { Angle formed by the long axis of the upper incisor and } \\
\text { the long axis of the lower incisor }\end{array}$ \\
\hline 8) $\mathrm{NL}$ & Angle formed by the columella line and the upper lip \\
\hline 9) $M L$ & $\begin{array}{l}\text { Supplement of the angle formed by the line of the lower } \\
\text { lip and the chin }\end{array}$ \\
\hline 10) UL_E & $\begin{array}{l}\text { Linear measure between the most prominent point of } \\
\text { the upper lip and the line } E\end{array}$ \\
\hline 11) $L L \_E$ & $\begin{array}{l}\text { Linear measure between the most prominent point of } \\
\text { the lower lip and the line } E\end{array}$ \\
\hline
\end{tabular}

\section{RESULTS}

To compare the changes that have occurred in the measurements, with and without treatment, it was necessary to eliminate the effect of the difference in time between the measurements performed in the experimental and control groups. For this reason, the changes in the measures were annualized (Table 5). The representation of the skeletal, dental and soft tissue changes is presented in Figure 3.
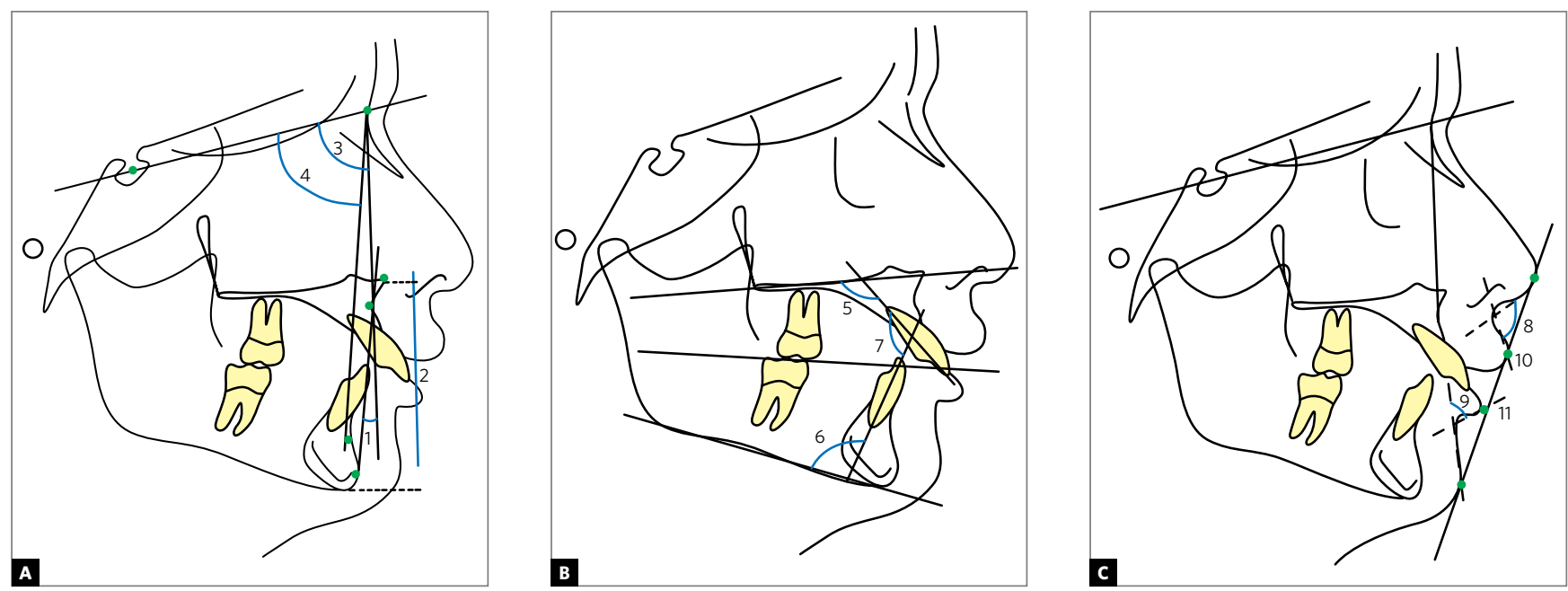

Figure 2 - Skeletal (A), dental (B) and soft tissue (C) cephalometric measures. 
Table 4 - Means and standard deviations of measures at baseline for each group, Levene's test for comparison of variances and Student's t-test to compare the means of the two groups.

\begin{tabular}{|c|c|c|c|c|c|c|c|c|c|}
\hline \multirow{2}{*}{ Measures } & \multicolumn{2}{|c|}{ Experimental group } & \multicolumn{2}{|c|}{ Control group } & \multicolumn{2}{|c|}{ Levene's test } & \multicolumn{3}{|c|}{ Student's t-test } \\
\hline & Mean & SD & Mean & SD & $F$ & $p$ & $t$ & df & $p$ \\
\hline Convex & 8.8 & 4.91 & 8.0 & 4.45 & 0.02 & 0.884 & 0.47 & 26 & 0.645 \\
\hline LAFH & 61.4 & 3.34 & 59.8 & 3.53 & 0.07 & 0.793 & 1.24 & 26 & 0.224 \\
\hline U1PP & 113.9 & 9.02 & 112.5 & 5.49 & 2.68 & 0.114 & 0.49 & 26 & 0.630 \\
\hline L1MP & 97.5 & 5.51 & 98.0 & 6.25 & 0.46 & 0.505 & -0.21 & 26 & 0.834 \\
\hline $\mathrm{NL}$ & 108.9 & 10.68 & 105.4 & 9.90 & 0.06 & 0.804 & 0.90 & 26 & 0.376 \\
\hline ML & 5.5 & 1.27 & 4.2 & 1.10 & 1.00 & 0.327 & 3.00 & 26 & 0.006 \\
\hline UL_E & 0.5 & 2.38 & -1.9 & 1.64 & 1.11 & 0.304 & 2.98 & 24 & 0.006 \\
\hline LL_E & 0.2 & 2.37 & -1.5 & 2.15 & 0.78 & 0.386 & 1.90 & 26 & 0.069 \\
\hline U1L1 & 120.9 & 11.70 & 122.3 & 8.31 & 0.57 & 0.456 & -0.36 & 26 & 0.719 \\
\hline SNA & 82.0 & 5.07 & 79.6 & 3.69 & 1.30 & 0.265 & 1.47 & 26 & 0.155 \\
\hline SNB & 77.3 & 3.95 & 75.0 & 2.38 & 2.65 & 0.115 & 1.81 & 26 & 0.082 \\
\hline
\end{tabular}

Table 5 - Means and standard deviations of annualized changes of measures for each group, Levene's test results for equality of variances and Student's t-test for equality of mean changes.

\begin{tabular}{|c|c|c|c|c|c|c|c|c|c|}
\hline \multirow{2}{*}{$\begin{array}{c}\text { Measure- } \\
\text { ment }\end{array}$} & \multicolumn{2}{|c|}{ Experimental group } & \multicolumn{2}{|c|}{ Control group } & \multicolumn{2}{|c|}{ Levene's test } & \multicolumn{3}{|c|}{ Student's t-test } \\
\hline & Mean & SD & Mean & SD & $F$ & $p$ & t & df & P \\
\hline Convex & -0.9 & 2.91 & 0.0 & 2.36 & 1.81 & 0.190 & -0.86 & 26 & 0.396 \\
\hline LAFH & 1.4 & 1.20 & 0.7 & 1.20 & 0.05 & 0.828 & 1.48 & 26 & 0.151 \\
\hline U1PP & -4.5 & 7.59 & -0.6 & 2.95 & 2.88 & 0.102 & -1.80 & 26 & 0.084 \\
\hline L1MP & 1.5 & 4.13 & 0.9 & 4.55 & 0.00 & 0.994 & 0.34 & 26 & 0.735 \\
\hline NL & 4.3 & 8.23 & 1.6 & 6.44 & 2.10 & 0.159 & 0.97 & 26 & 0.340 \\
\hline$M L$ & -0.8 & 0.94 & 0.1 & 0.58 & 3.49 & 0.073 & -3.10 & 26 & 0.005 \\
\hline UL_E & -0.7 & 1.21 & 0.0 & 1.24 & 0.03 & 0.866 & -1.50 & 26 & 0.145 \\
\hline LL_E & 0.3 & 1.26 & 0.5 & 1.03 & 0.04 & 0.845 & -0.44 & 26 & 0.662 \\
\hline U1L1 & 3.0 & 6.97 & 0.2 & 4.96 & 2.48 & 0.127 & 1.21 & 26 & 0.236 \\
\hline SNA & -0.6 & 1.55 & 0.4 & 1.91 & 0.04 & 0.843 & -1.45 & 26 & 0.160 \\
\hline SNB & 0.2 & 1.16 & 0.4 & 1.32 & 0.20 & 0.658 & -0.41 & 26 & 0.684 \\
\hline
\end{tabular}

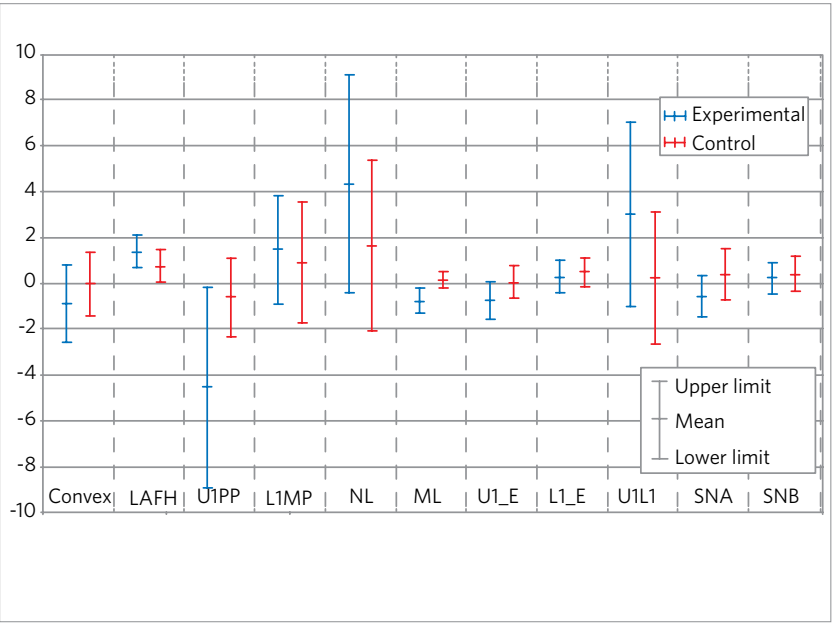

Figure 3 - Annualized changes: sample means and 95\% confidence intervals for the populational means.

\section{DISCUSSION}

The present study aimed to evaluate the changes in the facial profile of pre-pubertal individuals with Class II, division 1, mandibular retrusion, treated with Balters' bionator. In order to discriminate alterations induced by treatment from those deriving from natural growth, a control group was used from the Burlington Growth Centre, Toronto, Canada, which did not receive orthodontic treatment.

The knowledge about the growth process and natural craniofacial development is essential for distinguishing changes that truly occur by means of the established treatment, from those that occur regardless of the use of orthodontic appliances. However, one 
of the major methodological difficulties in clinical research, in the field of orthodontics, is the composition of a control group orthodontically untreated with similar characteristics to the experimental group. ${ }^{11}$ In the present study, it was used a control group from Canada, so it was possible to preserve the ethics, providing orthodontic treatment to all screened patients and eliminating a common bias for clinical work which is the absence of a control group.

In order to identify the actual stage of skeletal age, indicators of cervical vertebrae skeletal maturation were used based on the lateral teleradiographs, which are already part of the routine orthodontic records and therefore do not expose patients to additional X-rays, ${ }^{24}$ as it happens when hand and wrist radiographs are requested. In this study, all individuals were located in stages 1 or 2 of maturation, i.e. before pubertal growth peak period. ${ }^{4,21}$

The assessment of equivalency between the experimental and control groups on measures targeted at baseline (Table 4) showed great cephalometric similarities before treatment between groups, since only 2 of the 11 variables were statistically different.

Finally, it will be discussed the changes on the facial profile that occurred due to the functional orthopedic treatment (experimental group) and without interference from any device (control group).

\section{Effects of treatment}

After the trial period of one year, it was observed that the supplementary angle to skeletal convexity (Convex) showed a nonsignificant reduction of $0.9^{\circ}$ per year in the experimental group (Fig 3), while the control group did not change $\left(0.0^{\circ}\right.$ per year $)$, i.e. Balters' bionator provided a tendency towards improvement of facial convexity. These findings are in agreement with Melo ${ }^{19}$ whose studies about the changes on skeletal angle of convexity (NAPg) showed an increase of $2.52^{\circ}$ per year in children treated with bionator.

Considering that this angle is strongly influenced by the dislocation of the jaw bones during craniofacial growth and development, the behavior of anteroposterior jaw relative to the cranial base (SNA) was evaluated. It was identified that there was a tendency towards restriction of maxillary growth, known as extraoral effect, in the treated group $\left(-0.6^{\circ}\right.$ per year), while the control group showed an increase of $0.4^{\circ}$ per year (Fig 3 ). These data confirm the findings of Brandão ${ }^{7}$ who verified the decrease of SNA in patients treated with bionator. As for the jaw, the SNB angle showed no statistically significant change.

The balance in the relation between the upper lip and the nose is quite evident by the nasolabial angle, which is often associated with the characterization of facial esthetics. In this experiment, there was an increase of $4.3^{\circ}$ per year in the experimental group and $1.6^{\circ}$ per year in the control group (Fig 3). The data shows that there was a tendency for this angle to become more opened in the group receiving treatment and are in agreement with the findings of Silva and Dominguez-Rodriguez, ${ }^{28}$ who observed an increase of $9.83^{\circ}$ per year on a sample treated with bionator.

A determinant factor in the nasolabial angle is the postural position of the upper lip, which was assessed by checking the inclination of the upper incisor (U1PP). In the treated group, it was found a decrease of $4.5^{\circ}$ per year, highlighting the tendency towards vertical of maxillary incisors, whereas in the control group this decrease occurred on a much smaller scale $\left(-0.6^{\circ}\right.$ per year). As for the lower incisors, they tended to proclination, with a not statistically significant slight increase of $1.5 \mathrm{~mm}$ per year in group 1 and $0.9 \mathrm{~mm}$ per year in group 2 (Fig 1). We also assessed the interincisal angle (U1L1), which confirmed these aforementioned findings, with an increase of $3.0^{\circ}$ per year in the group receiving treatment and a slight increase of $0.2^{\circ}$ per year in the untreated group. Despite of lower incisors proclination being an undesired side effect of this treatment, this may contribute to postural correction of the lower lip. ${ }^{19}$

Assessing the behavior of the supplementary angle to mentolabial (ML), it was observed a statistically significant decrease $(p<0.05)$ of $0.8 \mathrm{~mm}$ per year for the treated group, whereas there was a tendency to an increase of $0.1 \mathrm{~mm}$ per year in the control group (Fig 3). This means that there was a significant improvement in the mentolabial angle for the treated group. These results are in agreement with the study of Silva and DominguezRodriguez, ${ }^{28}$ who observed an increase of $6.85^{\circ}$ in patients treated with bionator for 18 months. According to Blanchette et al, ${ }^{6}$ the mentum/labial sulcus of Class II children, with horizontal growth pattern and not submitted to orthodontic or orthopedic treatment, deepens naturally, which can be explained by the lower lip retracted and positioned between upper and lower incisors. 
Evaluating the performance of the variable LAFH, there was a non-significant increase in the treated group of $1.4 \mathrm{~mm}$ per year, while in the control group this increase occurred in a lower manner (0.7 $\mathrm{mm}$ per year), which means that there was a trend to increased lower anterior facial height, a fact also confirmed by Melo, ${ }^{19}$ who observed an increase in skeletal lower facial third of $1.37 \mathrm{~mm}$ per year in children treated with bionator.

Adding up the nose to the facial profile analysis, it was observed that the position of the upper lip to the line E (UL_E) showed a negative change of $0.8 \mathrm{~mm}$ per year (treatment group), while the control group did not show any alteration $(0.0 \mathrm{~mm}$ per year). Then, there was a tendency to retrusion of the upper lip, a fact confirmed by Lange et a $\mathrm{l}^{17}$ who demonstrated the existence of an upper lip retrusion of $1.0 \mathrm{~mm}$ per year in patients treated with Balters' bionator. Regarding the lower lip (LL_E), there was a slight tendency to protrusion of the lower lip in both groups, being higher in the group that received no treatment $(0.5 \mathrm{~mm} /$ year $)$.

The statistical analysis at a significance level of 5\% could not detect differences among most of the studied measures, except for the ML measure. It is noteworthy that, after a certain type of treatment, it is possible to find clinically detectable changes, but statistically insignificant, due to some factors such as the high variability of middle and/or high standard deviation, that may interfere on the effectiveness of the test used to identify these differences.

\section{CONCLUSION}

Considering the present study, it can be concluded that the effects produced by Balters' bionator on facial profile of children treated in the mixed dentition stage were:

» Increase of mentolabial angle.

" Tendency to decreased skeletal facial convexity.

" Tendency to maxillary growth restriction.

» Tendency to increased nasolabial angle.

» Tendency to verticalization of the upper incisors.

"Tendency to proclination of the lower incisors.

"Tendency to retrusion of the upper lip.

" Tendency to increased anterior facial height. 


\section{REFERENCES}

1. Ackerman JL. Orthodontics: art, science or transcience? Angle Orthod. 1974;44(3):243-50

2. Ascher F. The bionator in functional orthodontics. Inf Orthod Kieferorthop. 1984;16(3):215-46.

3. Angle $\mathrm{EH}$. Classification of malocclusion. Dent Cosmos 1899;41(3):248-64

4. Baccetti T, Franchi L, McNamara JA. The cervical vertebral maturation (CVM) method for the assessment of optimal treatment timing in dentofacial orthopedics. Semin Orthod. 2005;11:119-29.

5. Balters W. Betrachtugen uber Sinn und Zweck bei der funktionelli entwicklung des mundhohlenbereicher. Zahanartliche Welt, Heidelberg. 1950:5:460-3.

6. Blanchette ME, Nanda RS, Currier GF, Ghosh J, Nanda SK. A longitudinal cephalometric study of the soft-tissue profile of short and long face syndromes from 7 to 17 years. Am J Orthod Dentofacial Orthop. 1996:109(2):116-31.

7. Brandão RC. Avaliação cefalométrica do comportamento da mandíbula na interceptação da má oclusão classe II divisão 1 de Angle, com o Bionator [tese]. Araraquara (SP): Universidade Estadual Paulista; 2000.

8. Burstone CJ. The integumental profile. Am J Orthod. 1958:44(1):1-25.

9. Broadent $\mathrm{H}$. A new x-ray technique and its application to Orthodontia. Angle Orthod. 1931;1(2):45-66.

10. Case CS. Facial and oral deformities. Chicago: CS Case; 1986

11. Cozza P, Baccetti T, Franchi L, De Toffol L, McNamara JA Jr. Mandibular changes produced by functional appliances in class II malocclusion: A systematic review. Am J Orthod Dentofacial Orthop. 2006;129(5):599 e1-12; discussion e1-6.

12. Dale J. Interceptive guidance of occlusion with emphasis on diagnosis In: Graber TM, Vanarsdall RL. Orthodontics, current principles and techniques. $2^{\text {nd }}$ ed. St. Louis: Mosby; 1994. p. 375-469.

13. Eirew HL. The Bionator. Br J Orthod. 1981;8(1):33-6.

14. Hambleton RS. The soft tissue covering of the skeletal face as related to orthodontic problems. Am J Orthod Dentofacial Orthop. 1964;50(6):405-20

15. Henry RG. A classification of Class II division 1 malocclusion. Angle Orthod. 1957:27(3):83-92

16. Nanda RS, Ghosh J. Facial soft-tissue harmony and growth in orthodontic treatment. Semin Orthod. 1981;1(2):67-81.

17. Lange DW, Kalra V, Broadbent BH Jr, Powers M, Nelson S. Changes in soft tissue profile following treatment with the bionator appliance. Angle Orthod. 1995:65(6):423-30.
18. Martins JCR, Sinimbú CMB, Dinelli TCS, Martins LPM, Raveli DB. Prevalência da má oclusão em pré-escolares de Araraquara: relação da dentição decídua com hábitos bucais e nivel socioeconômico. Rev Dental Press Ortod Ortop Facial. 1998;3(6):35-43.

19. Melo ACM. Mudanças no perfil facial de crianças com má oclusão classe II, divisão 1 decorrentes do crescimento normal e induzidas pelo Bionator de Balters [tese]. Araraquara (SP): Universidade Estadual Paulista; 2003.

20. Nguyen DD, Turley PK. Changes in the Caucasian male profile as depicted in fashion magazines during the twentieth century. Am J Orthod Dentofacial Orthop. 1998:114(2):208-17.

21. O'Reilly MT, Yanniello GJ. Mandibular growth changes and maturation of cervical vertebrae - a longitudinal cephalometric study. Angle Orthod. 1988;58(2):179-84

22. Pancherz $H$, Anehus-Pancherz M. Facial profile changes during and after Herbst appliance treatment. Eur J Orthod. 1994;16(4):275-86.

23. Peck H, Peck S. A concept of facial esthetics. Angle Orthod 1970;40(4):284-317

24. Raveli DB, Goes DR, Dib LPS. Avaliação da maturidade esquelética através das vértebras cervicais. Ortodontia SPO. 2006:34(4):362-64.

25. Riedel RA. An analysis of dentofacial relationships. Am J Orthod Dentofacial Orthop. 1957:43(2):103-19.

26. Romani KL, Agahi F, Nanda R, Zernik JH. Evaluation of horizontal and vertical differences in facial profiles by orthodontists and lay people. Angle Orthod. 1993:63(3):175-82.

27. Scavone Jr H. O perfil facial tegumentar dos 13 aos 18 anos de idade [tese]. Bauru (SP): Universidade de São Paulo; 1996.

28. Silva SV, Dominguez-Rodriguez GC. Estudo comparativo cefalométrico radiográfico das mudanças do perfil tegumentar de adolescentes com má oclusão de classe $I$, divisão $1^{a}$ e retrognatismo mandibular, tratados com bionator de Balters. Ortodontia. 2002;38(3):43-56

29. Silva Filho OG, Freitas SF, Cavassan AO. Prevalência de oclusão normal e má oclusão na dentadura mista em escalares da cidade de Bauru (São Paulo). Rev Assoc Paul Cir Dent. 1989:43:287-90

30. Silva Filho OG, Silva PRB, Rego MVNN, Silva FPL, Cavassan AO. Epidemiologia da má oclusão na dentadura decídua. Ortodontia. 2002;33(2):22-33 